\title{
Infection Processes and Involvement of Defense-Related Genes in the Expression of Resistance in Cultivars of Subterranean Clover (Trifolium subterraneum) to Phytophthora clandestina
}

\author{
X. Ma, Hua Li, K. Sivasithamparam, and M. J. Barbetti \\ First, second, third, and fourth authors: School of Plant Biology, Faculty of Natural and Agricultural Sciences, The University of Western \\ Australia, Crawley, WA 6009, Australia; and fourth author: Department of Agriculture and Food Western Australia, Baron-Hay Court, \\ South Perth, WA 6151, Australia. \\ Accepted for publication 20 December 2009.
}

\begin{abstract}
Ma, X., Li, H., Sivasithamparam, K., and Barbetti, M. J. 2010. Infection processes and involvement of defense-related genes in the expression of resistance in cultivars of subterranean clover (Trifolium subterraneum) to Phytophthora clandestina. Phytopathology 100:551-559.

Studies on infection processes and gene expression were done to determine differential responses of cultivars of Trifolium subterraneum resistant and susceptible to infection by races of Phytophthora clandestina. In the infection process study, one race was inoculated onto the roots of $T$. subterraneum cvs. Woogenellup and Junee (compatible or incompatible interactions, respectively). There were no differences in relation to the processes of cyst attachment, germination, and hyphal penetration. There were, however, major differences in infection progression observed post-penetration between compatible and incompatible interactions. In susceptible cv. Woogenellup, hyphae grew into the vascular bundles and produced intercellular antheridia and oogonia in the cortex and stele by 4 days postinoculation (dpi), oospores in the cortex

prevented emergence of lateral roots. Roots of resistant cv. Junee showed no oospores or sporangia and no disease at $8 \mathrm{dpi}$. In the gene expression studies, two races of $P$. clandestina were inoculated onto three cultivars of T. subterraneum. Results showed that three genes known to be associated with plant defense against plant pathogens were differentially expressed in the roots during compatible and incompatible interactions. Phenylalanine ammonia lyase and chalcone synthase genes were activated $4 \mathrm{~h}$ postinoculation (hpi) and cytochrome P450 trans-cinnamic acid 4-monooxygenase gene was activated $8 \mathrm{hpi}$ in the incompatible interactions in cvs. Denmark and Junee following inoculation with Race 177. In contrast, in compatible interactions in cv. Woogenellup, there were no significant changes in the activation of these three genes following inoculation, indicating that these three genes were associated with the expression of resistance to Race 177 of the pathogen by the host. To confirm this result, in the second test, cv. Woogenellup was challenged by Race 000 of $P$. clandestina. In this incompatible interaction, cv. Woogenellup was resistant and expressed highly all three genes in the manner similar to the incompatible interactions observed in the first test.
\end{abstract} and stele by $8 \mathrm{dpi}$, when sporangia were evident on the surface of the root. Infected taproots were discolored. Early destruction of taproots

Phytophthora clandestina is a major cause of decline in the productivity of subterranean clover (Trifolium subterraneum) pastures with a capacity to reduce annual production of subterranean clover by more than $90 \%(2,17)$. Root disease caused by $P$. clandestina remains the most serious threat to pasture productivity across Australia (2). To date, this pathogen has not been recorded outside of Australia (14).

The main method of control of $P$. clandestina is host resistance $(2,27)$. However, it was not until the work of You et al. (33), who characterized a total of 10 pathogenic races among approximately 100 Western Australian isolates, that the first clear picture of the racial distribution of $P$. clandestina became evident. That work provided a basis for the selection and breeding of appropriate $T$. subterraneum cultivars to counter the predominant race populations occurring in specific localities. Although Purwantara et al. (28) studied the colonization of roots of subterranean clover

Corresponding author. H. Li; E-mail address: hli@cyllene.uwa.edu.au

* The $\boldsymbol{e}$-Xtra logo stands for "electronic extra" and indicates that the online version contains a figure showing the RNA transcription levels of $18 \mathrm{~S}$ and ACT genes for compatible and incompatible interactions sampled $0,2,4,8,12$, and $24 \mathrm{~h}$ postinoculation.

doi:10.1094/PHYTO-100-6-0551

(C) 2010 The American Phytopathological Society
Additional keywords: pastures, plant-microbe interactions. cultivars by virulent and avirulent races of $P$. clandestina, the infection processes and gene expression related to host resistance in this pathosystem have not been studied in detail.

In plant-pathogen interactions, different host cultivars often exhibit specific responses to different physiological races of the pathogen. Many plant genes, including those related to antimicrobial enzymes such as phenylalanine ammonia lyase (PAL), chalcone synthase (CHS), cytochrome P450 trans-cinnamic acid 4-monooxygenase (CYP), chitinase, glucanase, peroxidases, and coumaric acid 4-hydroxylase $(\mathrm{C} 4 \mathrm{H})$ have been identified as defense-related due to their responses to pathogen infection in relatively tolerant/resistant plants. Expression of these enzymes is associated with defense responses to infections by Phytophthora spp. and other plant pathogens in various plant species, such as soybean (24), potato (32), and alfalfa (29). PAL and CHS have been widely studied because they are key enzymes of the phenylpropanoid pathway that leads to phytoalexin accumulation. CYP was also reported to play an important role in the defense response of pepper to infection by a Colletotrichum sp. (25). However, no information on the involvement of these genes in resistance in subterranean clover to the races of $P$. clandestina has been reported.

Determining infection processes involved in the expression or suppression of susceptibility is crucial to understanding the mechanisms of defense-related gene expression. The recent development of real-time quantitative reverse transcription-polymer- 
ase chain reaction (QRT-PCR) assays has allowed the accurate expression-profiling of RNA transcripts. This technology has become the most useful method for characterizing gene expression in plant-microbe interactions in general (23) and specifically to monitor the activation of genes related to plant defenses against fungal pathogens $(6,21)$.

This paper reports results of a microscopy study of the responses of resistant and susceptible cultivars of $T$. subterraneum to infection by one race of $P$. clandestina in relation to the cyst attachment, germination, and hyphal penetration associated with infection and symptom development. An associated study using real-time QRT-PCR was conducted to determine the rates of expression of resistance-related genes in three cultivars of $T$. subterraneum to infection by a virulent and an avirulent race of $P$. clandestina.

\section{MATERIALS AND METHODS}

$P$. clandestina isolate used. One isolate of $P$. clandestina, UWA Phy-14-2, was used for the microscopy study. Isolates UWA Phy14-2 and UWA Phy-B4 were used for the molecular study. Both isolates were collected in May 2007 from field-grown subterranean clover plants in Western Australia. Isolate UWA Phy-14-2 belongs to Race 177 and isolate UWA Phy-B4 belongs to Race 000 , based on the pathogenicity tests on differential hosts as described previously (33). Isolates were stored as colonized Lima bean agar (LBA) plugs in sterile water at $4^{\circ} \mathrm{C}$, and when required for the screening tests, subcultured on to fresh LBA and maintained at $18^{\circ} \mathrm{C}$.

Plant cultivars tested. Two cultivars of T. subterraneum viz, Woogenellup and Junee, were used for the microscopy study. Three cultivars viz, Woogenellup, Denmark, and Junee, were used for the molecular study. Cultivar Woogenellup is susceptible to isolate UWA Phy-14-2 (Race 177), and cvs. Denmark and Junee are resistant to it. All three cultivars are resistant to isolate UWA Phy-B4 (Race 000).

Inoculation for the microscopy study. Inoculum was prepared by washing in sterile deionized water 5-day-old mycelial cultures of $P$. clandestina grown in LBA and incubated in sterile pond water (SPW) in petri dishes (one mat/dish) at $20^{\circ} \mathrm{C}$ for $14 \mathrm{~h}(6 \mathrm{~h}$ light followed by $8 \mathrm{~h}$ darkness) to stimulate production of sporangia. Two mycelial mats were then transferred to $20 \mathrm{ml}$ of SPW in separate petri dishes. Dishes were incubated at $4{ }^{\circ} \mathrm{C}$ for $10 \mathrm{~min}$ and then at $18^{\circ} \mathrm{C}$ for $2 \mathrm{~h}$ to induce release of zoospores from the sporangia. Mats were removed from the SPW and the concentration of zoospores was determined using a hemacytometer.

Seeds of the two cultivars used were surface-sterilized with $1 \%$ sodium hypochlorite solution. Seeds were germinated in petri dishes before inoculation. Three-day-old seedlings were placed in $20 \mathrm{ml}$ of the suspension of zoospores $\left(14,000 \mathrm{ml}^{-1}\right)$ in a petri dish and incubated at $18^{\circ} \mathrm{C}$. After $2 \mathrm{~h}$ the SPW was gently pipetted out of the dishes and the seedlings reincubated on sterile filter paper. Uninoculated seedlings were placed in SPW before being transferred on to sterile filter paper.

Inoculation for the molecular study. Inoculum was prepared by colonizing sterile moist millet (Panicum miliaceum) seeds by soaking $200 \mathrm{~g}$ of millet seeds in deionized water in a 1-liter flask for $12 \mathrm{~h}$, excess water was drained and then autoclaved at $121^{\circ} \mathrm{C}$ for $20 \mathrm{~min}$ on three consecutive days. Two-week-old P. clandestina colonies growing on LBA plates were cut to plugs of $2 \mathrm{~mm}^{2}$ (20 added per flask) and used to inoculate each flask containing the prepared sterile moist millet seed. The flasks were vigorously shaken every 2 days to ensure uniform colonization and incubated in the dark at $22^{\circ} \mathrm{C}$ for 2 weeks.

The seeds of the three cultivars tested were surface-sterilized with $1 \%$ sodium hypochlorite solution. Seeds were germinated in petri dishes before inoculation. Four-day-old seedlings were uniformly mixed with the $P$. clandestina-colonized millet inoculum and incubated for $2 \mathrm{~h}$. Noninfected seedlings were placed in petri dishes and used as control comparisons.

Inoculated seedlings (both for microscopy and molecular studies) were transplanted into pots of steam-sterilized UWA potting mix and watered daily to maintain field capacity. After 3 weeks, the severity of root disease on each seedling was rated on a scale of 0 to 5 based on that used by Flett (16) and later modified by Aldaoud et al. (1): 0, healthy roots; 1 , lateral root discoloration; 2, 1/3 taproots discolored; 3, 2/3 of taproots discolored; 4, taproots rotted away, no new lateral roots; and 5, seedling dead.

To confirm that disease symptoms observed were in fact caused by $P$. clandestina, $2 \mathrm{~cm}$ root segments were taken from affected roots of each cultivar and floated in separate petri dishes containing sterile deionized water for 2 days at $22^{\circ} \mathrm{C}$ and then examined microscopically for the presence of typical sporangia of P. clandestina as described by Erwin and Ribeiro (14).

Sample collection for the scanning electron microscopy study. Roots were sampled at $0,2,4,6$, and $8 \mathrm{~h}$ postinoculation (hpi). Fresh segments (4 to $6 \mathrm{~mm}$ ) of infected roots were vacuum infiltrated for $5 \mathrm{~min}$ and fixed in $2.5 \%$ glutaraldehyde in $0.05 \mathrm{M}$ phosphate buffer, $\mathrm{pH} \mathrm{7,} \mathrm{for} 24 \mathrm{~h}$ at room temperature. Samples were dehydrated and coated with gold particles and photographed and studied using a Philips XL30 scanning electron microscopy.

Sample collection for the light microscopy study. Roots were sampled at $1,2,4,5,7$, and 8 days postinoculation (dpi). Hand sections of root tips were placed in $10 \% \mathrm{NaOH}$ solution over night, and then changed into $0.05 \%$ aniline blue in $\mathrm{K}_{2} \mathrm{HPO}_{4}$, $\mathrm{pH}$ 9.0, buffer before examination and photographed with an Olympus BX 51 microscope system with an excitation filter (G365) and an emission filter (LP 420) inserted into a beam of incident light from a mercury vapor lamp. Roots also were sampled at $0,2,4,6$, and 8 hpi and 1, 2, and 4 dpi. Hand sections were stained with aniline blue before examination as described and photographed.

RNA extraction. Infected (treatment) and noninfected (control) seedlings were harvested at $0,2,4,8,12$, and 24 hpi. Three replicates were collected per treatment/control. In order to avoid cross-contamination with the pathogen, seedlings were thoroughly washed with distilled water and blot-dried with filter paper. Samples were stored at $-80^{\circ} \mathrm{C}$. Total RNA was extracted from 100 $\mathrm{mg}$ of ground tissue using the RNeasy Plant Mini Kit (Qiagen, Doncaster, Australia) and contaminating DNA was removed using the Turbo DNA-free Kit (Ambion, Scoresby, Australia) according to the manufacturers' protocols. Contamination of residual genomic DNA in all RNA samples was tested by amplification using the method described below. If genomic DNA was found to be present, a further DNase treatment (Promega, Sydney, Australia) was carried out according to the manufacturer's protocol and the sample was retested. Prior to transcription experiments, the concentration and integrity of RNA were verified by an optical density (OD) at $260 \mathrm{~nm} \mathrm{OD}_{260} / \mathrm{OD}_{280}$ absorption ratio using a Nanodrop spectrophotometer and electrophoresis on a denaturing agarose gel.

Primer design. Primers used in this study (Table 1) were designed based on mRNA sequences of Trifolium species deposited in GenBank, or from previous reports $(12,13,30)$. The specificity of the primers was checked by alignments with the original GenBank sequences using the Blastn algorithm, as provided online by NCBI. Primer pair PALF/PAL1R was designed to span an intron within the PAL gene. It was used to distinguish contaminating genomic DNA from cDNA by generating different sized amplicons. Two primer sets (18SF/18SR, ACTF/ACTR) are designed for reference genes (18S ribosomal RNA and actin). RT-PCR and PCR assays followed by gel electrophoresis were performed to verify the amplification of cDNA and genomic DNA using the designed primers. Melting 
point analysis was performed at the end of the real-time RT-PCR to confirm the amplification of a unique product for each gene.

cDNA synthesis and amplification of defense-related genes by RT-PCR. Two-step RT-PCR was performed. Reverse-transcription was carried out for $60 \mathrm{~min}$ at $37^{\circ} \mathrm{C}$ in a $20 \mu$ reaction volume containing $0.2 \mu \mathrm{g}$ of oligo-dT primer (Qiagen) and 4 units of Omniscript Reverse Transcriptase. The cDNAs synthesized were used as templates for PCR assays using specific primers (Table 1).

Amplification was performed in a $10 \mu \mathrm{l}$ reaction mixture containing $5 \mu \mathrm{l}$ of $2 \times$ GoTaq Green master mix (Promega), $0.5 \mu \mathrm{l}$ of each primer $(10 \mu \mathrm{M}), 4.2 \mu \mathrm{l}$ of nuclease free water, and $0.4 \mu \mathrm{l}$ of cDNA. The amplification conditions were $94^{\circ} \mathrm{C}$ for $2 \mathrm{~min}$, followed by 30 cycles of $94^{\circ} \mathrm{C}$ for $1 \mathrm{~min}, 50$ to $55^{\circ} \mathrm{C}$ for $1 \mathrm{~min}$, and $72^{\circ} \mathrm{C}$ for $1 \mathrm{~min}$. Following amplification, a $10 \mathrm{~min}$ extension at $72^{\circ} \mathrm{C}$ was added at the end of the run. In all RT-PCR runs, appropriate negative controls containing no cDNA template were subjected to the same treatment.

The RT-PCR products were quantified using a Nanodrop spectrophotometer. RT-PCR products were used to prepare serial dilutions to generate standard curves for real-time QRT-PCR assays.

DNA sequencing of selected genes. RT-PCR products were sequenced with BigDye version 3.1 chemistry (Applied Biosystems Industries (ABI), Scoresby, Australia) using an ABI/ Hitachi 3730 DNA Analyzer. DNA sequence data were compared with other sequences on GenBank using the Blastn algorithm.

Gene expression analysis by real-time QRT-PCR. Real-time QRT-PCR was performed on cDNA (see above for synthesis conditions) of each of the defense-related genes and for 18S RNA as a reference. The reactions were performed on a LightCycler 480 (Roche, Dee Why, Australia) thermocycler. Reaction mixtures were prepared using the following ingredients: $5 \mu \mathrm{l}$ of $2 \times$ SYBR Green I master mix (Roche), $0.5 \mu$ l of each primer $(10 \mu \mathrm{M})$ set (Table 1), and $4 \mu \mathrm{l}$ of diluted cDNA or standard solution as template. The amplification conditions were $95^{\circ} \mathrm{C}$ for $10 \mathrm{~min}$ of preincubation, followed by 45 cycles of amplification at $95^{\circ} \mathrm{C}$ for $10 \mathrm{~s}, 50$ to $55^{\circ} \mathrm{C}$ for $10 \mathrm{~s}, 72^{\circ} \mathrm{C}$ for $20 \mathrm{~s}$. Following amplification, a melting curve program $\left(65\right.$ to $95^{\circ} \mathrm{C}$ with a heating rate of $0.1^{\circ} \mathrm{C} / \mathrm{s}$ ) and finally a cooling step to $40^{\circ} \mathrm{C}$ were added.

The Fit Points Method was performed using LightCycler software version 1.5 for analysis of the standard curve. A linear relationship was obtained for each run by plotting threshold cycle numbers (CTs) against the logarithm of cDNA copies of a set of standard solutions. The equation of the line that best fitted the data was determined by regression analysis. The $R^{2}$ value was calculated to estimate the accuracy of the real-time RT-PCR as a quantification method. Slope of the standard curve was used to calculate efficiency of the real-time QRT-PCR according to the formula $\mathrm{E}=\left(10^{(-1 / \mathrm{slope})}\right)-1$. Relative quantification ratio changes of defense-related gene transcripts in different treatments versus control (i.e., mock treatment) were normalized using the CT and efficiency obtained for the reference gene amplification run on the same cDNA templates using the formula below (26):

$$
\mathrm{R}=\left[\left(\mathrm{E}_{\text {target }}\right)^{\Delta \mathrm{Ct} \text { target(control - sample) })}\right] /\left[\left(\mathrm{E}_{\text {reference }}\right)^{\Delta \mathrm{Ct} \text { reference(control - sample) }}\right]
$$

where $\mathrm{R}$ is relative quantification ratio, $\mathrm{E}_{\text {target }}$ is the real-time RTPCR efficiency of a target gene transcript, $\mathrm{E}_{\text {reference }}$ is the real-time RT-PCR efficiency of the reference gene transcript, $\Delta \mathrm{CT}_{\text {target }}=\mathrm{CT}$ deviation of control - sample of the target gene transcripts, and $\Delta \mathrm{CT}_{\text {reference }}=\mathrm{CT}$ deviation of control - treatment of reference gene transcripts.

Statistical analysis. Relative quantification ratios of defenserelated gene transcripts were tested for significant difference between sampling time and inoculation treatments using two-way analysis of variance (ANOVA) using GenStat. Because the ANOVA indicated time course and treatment were significant $(P<0.05)$, pair-wise comparisons of treatments were done using a Tukey test.

\section{RESULTS}

The infection process. The infection processes of zoospores of $P$. clandestina, isolate UWA Phy-14-2, to both the susceptible (Woogenellup) and resistant (Junee) cultivars of subterranean clover are presented in Table 2. Zoospores of P. clandestina, isolate UWA Phy-14-2, swam to the tips of seedling taproots of both the susceptible (Woogenellup) and resistant (Junee) cultivars studied, where they encysted on the root surface (Fig. 1A). Cysts germinated within 1 to $2 \mathrm{hpi}$. Then the tips of the germ tubes penetrated the roots of both cultivars (2 to 4 hpi) (Fig. 1B and C). Sometimes, the tips of the germ tubes became swollen and formed an appressorium like structure (Fig. 1D) and then penetrated the root. Penetration of roots occurred mainly between anticlinal walls of adjoining epidermal cells (Fig. 1B). Up until

TABLE 1. Primers designed and used in real-time reverse transcription-polymerase chain reaction for amplifying defense-related genes and reference genes of Trifolium subterraneum

\begin{tabular}{|c|c|c|c|c|c|c|}
\hline $\begin{array}{l}\text { Target } \\
\text { gene }\end{array}$ & Primer name & Primer sequence $\left(5^{\prime}-3^{\prime}\right)$ & $\begin{array}{l}\text { Size for genomic } \\
\text { DNA (bp) }\end{array}$ & $\begin{array}{l}\text { Size for } \\
\text { cDNA (bp) }\end{array}$ & $\begin{array}{c}\text { GenBank } \\
\text { accession no. }\end{array}$ & Reference \\
\hline PAL & $\begin{array}{l}\text { PALF } \\
\text { PAL1R } \\
\text { PALF } \\
\text { PALR }\end{array}$ & $\begin{array}{l}\text { GCGTATGGTGGAGGAGTACC } \\
\text { CTCTCCATAACCCAGTCACTG } \\
\text { GCGTATGGTGGAGGAGTACC } \\
\text { TGTGTGTGGTAGTGTGTGGC }\end{array}$ & 162 & 162 & $\begin{array}{c}\text { N/A } \\
\text { FJ269038 }\end{array}$ & $\begin{array}{l}\text { This project } \\
\text { This project }\end{array}$ \\
\hline CHS3 & $\begin{array}{l}\text { CHS3F } \\
\text { CHS3R }\end{array}$ & $\begin{array}{l}\text { GGGAATTTCTGATTACAACTC } \\
\text { AACAGTCTCAATGGTAAGTCCT }\end{array}$ & 276 & 276 & FJ269039 & This project \\
\hline CCR & $\begin{array}{l}\text { CCRF } \\
\text { CCRR }\end{array}$ & $\begin{array}{l}\text { GTGTTGATGTAGAGGTTGATG } \\
\text { GTATGTGAGCTAATGCAACAT }\end{array}$ & 392 & 392 & TC106830 & (13) \\
\hline CYP & $\begin{array}{l}\text { CYPF } \\
\text { CYPR }\end{array}$ & $\begin{array}{l}\text { TCAAAGATTGACACTTCTGAG } \\
\text { AAAAATCATCTCAAAACCATT }\end{array}$ & 233 & 233 & FJ269040 & (13) \\
\hline SE & $\begin{array}{l}\text { SEF } \\
\text { SER }\end{array}$ & $\begin{array}{l}\text { CGCGGATCCATGGATCTATACAATATCGGTTGG } \\
\text { CTAGCTAGCTCAAAATGCATTTACCGGGGGAGC }\end{array}$ & & & TC51619 & (31) \\
\hline
\end{tabular}


this stage of the infection process, no apparent differences between cultivars were evident.

Differences in the infection process of the two cultivars became visible from 4 dpi. In cv. Woogenellup, the hyphae grew into the

TABLE 2. The infection processes of zoospores of Phytophthora clandestina, isolate UWA Phy-14-2 (Race 177) in both a susceptible (Woogenellup) and a resistant (Junee) cultivar of Trifolium subterraneum at various times (hours postinoculation [hpi] or days postinoculation [dpi])

\begin{tabular}{|c|c|c|}
\hline \multirow[b]{2}{*}{ Time } & \multicolumn{2}{|c|}{ T. subterraneum cultivar } \\
\hline & Woogenellup (susceptible) & Junee (resistant) \\
\hline 2 to 4 hpi & Cysts germinated and penetrated & $\begin{array}{l}\text { Cysts germinated and } \\
\text { penetrated }\end{array}$ \\
\hline 4 dpi & Hyphae in vascular bundles & Hyphae in cortical cells \\
\hline 5 dpi & $\begin{array}{l}\text { Hyphae heavily colonized the } \\
\text { stele, especially in the } \\
\text { endodermis and pericycle cells. } \\
\text { These cells were discolored. } \\
\text { Antheridia and oogonia evident } \\
\text { in the cortex and stele }\end{array}$ & $\begin{array}{l}\text { Hyphae in four to six } \\
\text { layers of cortical cells } \\
\text { but no antheridia or } \\
\text { oogonia }\end{array}$ \\
\hline 8 dpi & $\begin{array}{l}\text { Presence of oospores in the } \\
\text { cortex and stele and sporangia } \\
\text { on the surface of the root; } \\
\text { tap roots discolored with no } \\
\text { lateral roots }\end{array}$ & $\begin{array}{l}\text { No oospores or sporangia } \\
\text { evident, tap roots } \\
\text { appear to be unaffected } \\
\text { and carrying healthy } \\
\text { lateral (branched) roots }\end{array}$ \\
\hline
\end{tabular}

vascular bundles (Fig. 2A) and were mainly intercellular, but sometimes intracellular in the cortex and stele. However, in cv. Junee, the hyphae invaded four to five layers of cortical cells (mainly intercellular, but some times intracellular) (Fig. 2B). At 5 dpi in cv. Woogenellup, $P$. clandestina had heavily colonized the stele, especially in the endodermis and pericycle cells (Fig. 2C). The endodermis and pericycle cells were discolored. $P$. clandestina also produced intercellular antheridia and oogonia in the cortex and stele (Fig. 2D). At the same time in cv. Junee, the hyphae had invaded four to six layers of cortical cells and there was no evidence of antheridia or oogonia in the cortical layers. In cv. Woogenellup, intercellular oospores were present in the cortex and stele by 8 dpi (Fig. 2E), with sporangia present on the surface of the root (Fig. 2G). By this stage, in cv. Junee, the hyphae had just reached the stele (Fig. 2F). At 8 dpi, in cv. Woogenellup, the infected taproots were discolored with no lateral roots (Fig. 2H). In comparison, the roots of cv. Junee at this time showed no oospores or sporangia, with the infected taproots appearing to be unaffected and carrying healthy lateral (branched) roots (Fig. 2I).

Defense-related gene transcripts, standard curves, and sensitivity of real-time QRT-PCR. Conventional RT-PCR runs, using cDNA as template by all designed primer pairs produced single products of expected sizes. The amplicon size of the PAL gene showed that genomic DNA contamination was eliminated after treatments to eliminate it. Glutathione S-transferase, cinna-
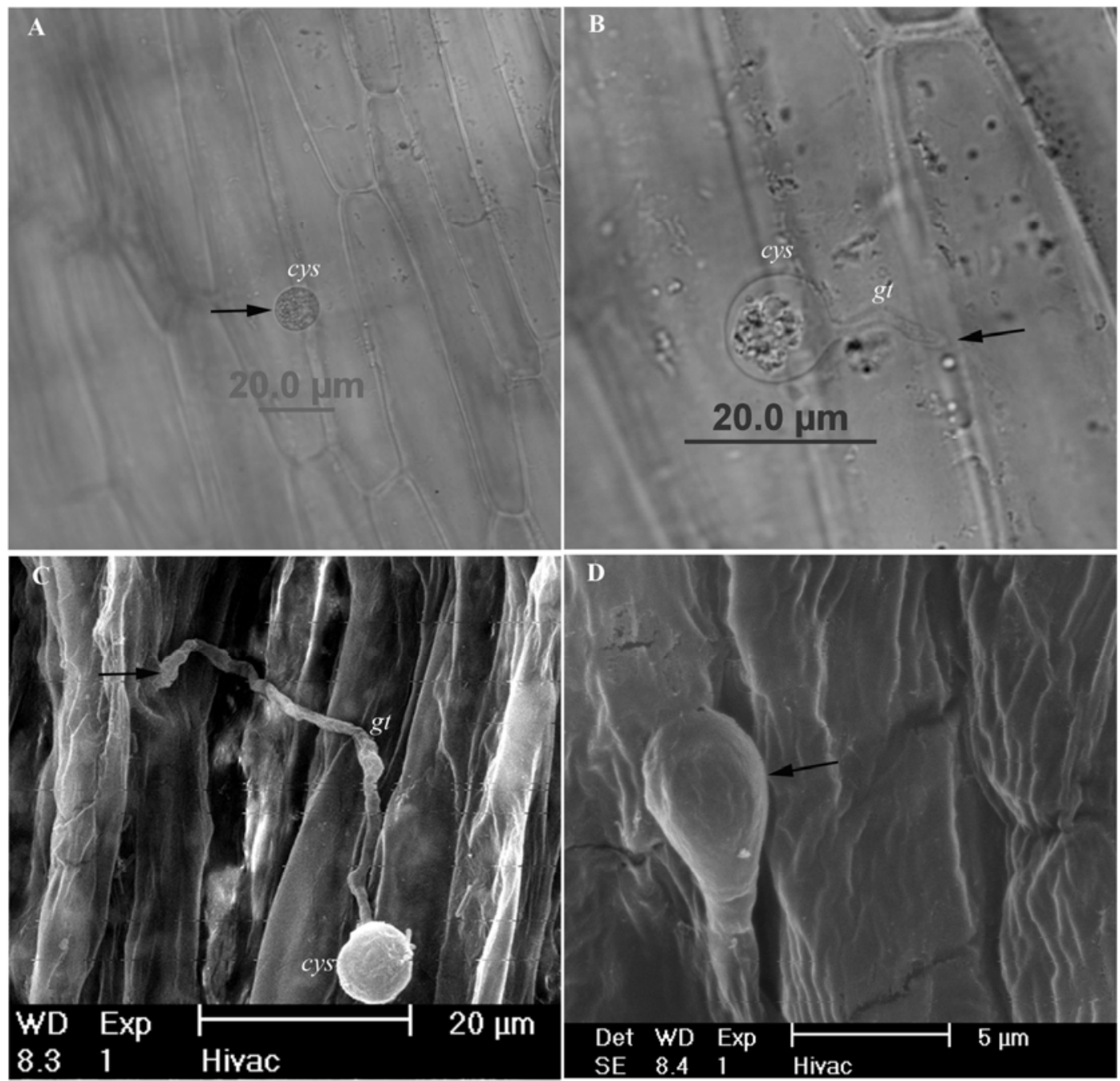

Fig. 1. Cyst of Phytophthora clandestina, isolate UWA Phy-14-2 (Race 177), germinating and penetrating the surface of root of susceptible (Woogenellup) and resistant (Junee) cultivars. A, A zoospore encysted on the root surface (arrow) at $1 \mathrm{~h}$ postinoculation (hpi). B, Cyst germinated and starting to penetrate (arrow) at 2 hpi. C, Germ tube has reached the anticlinal walls of adjoining epidermal cells and penetrated the root (arrow) at 4 hpi. D, The tip of the germ tube has swollen and formed an appressorium-like structure (arrow) at 4 hpi. cys $=$ cyst, $g t=$ germ tube. 

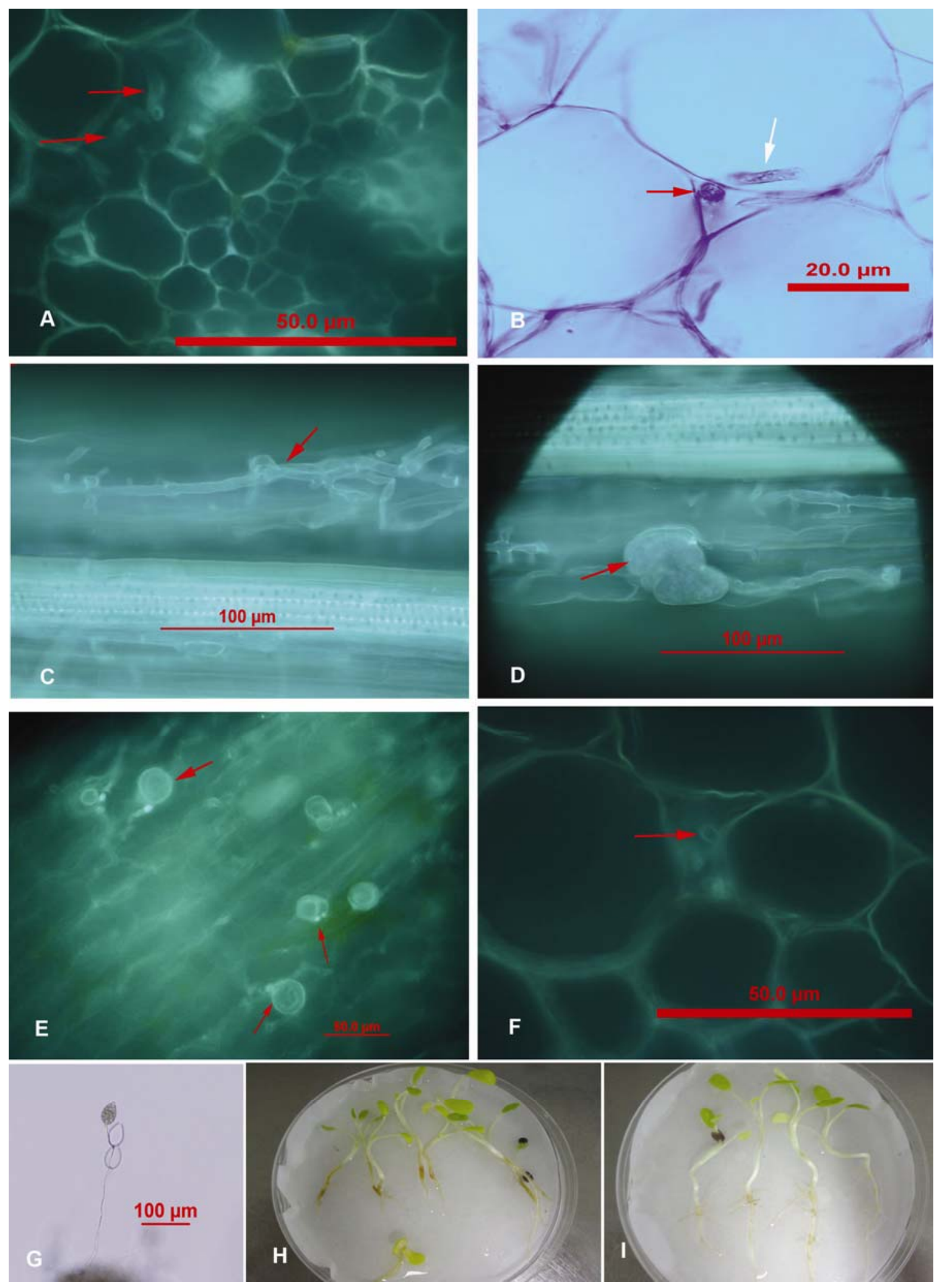

Fig. 2. Roots of seedlings of both cultivars Woogenellup (susceptible) and Junee (resistant) inoculated by zoospores of Phytophthora clandestina. A, Infected section of cv. Woogenellup at 4 days postinoculation (dpi). Arrows indicate hyphae have penetrated into the endodermis cells. B, Infected section of cv. Junee at 4 dpi. Hyphae have invaded four to five layers of cortical cells (red arrow indicating intercellular hyphae, white arrow indicating intracellular hyphae). C, Infected section of cv. Woogenellup at 5 dpi. P. clandestina has heavily colonized the stele, especially in the endodermis and pericycle cells (arrow). D, Antheridia and oogonia produced in cv. Woogenellup in the stele (arrow) at $5 \mathrm{dpi}$. E, Oospores (arrows) present in the cortex and stele in cv. Woogenellup by $8 \mathrm{dpi}$. F, In cv. Junee at $8 \mathrm{dpi}$, the hyphae just reaching the stele. G, Sporangia present on the surface of the root of cv. Woogenellup at $8 \mathrm{dpi}$. H, Discolored taproot of cv. Woogenellup with no lateral roots. I, Infected taproot of cv. Junee appearing to be symptomless and carrying healthy lateral (branched) roots. A, C, D, E, and F are aniline blueUV fluorescence microscopy images. 
moyl-CoA reductase, and squalene epoxidase genes did not yield amplification products. This indicated that these genes were not expressed during this pathogen-plant interaction.

A LightCycler melting curve analysis for each primer set resulted in single products with the following specific melting temperatures: PALF/PAL1R, $75.5 \pm 1.32^{\circ} \mathrm{C}$; CYP, $75.17 \pm$ $0.23^{\circ} \mathrm{C}$; CHS3, $78.83 \pm 1.33^{\circ} \mathrm{C}$; and $18 \mathrm{~S}, 86.74 \pm 1.18^{\circ} \mathrm{C}$.

Standard curves for each of the four genes (PAL, CHS, CYP, and 18S) were constructed using serial dilutions of amplicons. Depending on the gene, dilution of $10^{6}$-fold of target transcripts could be reproducibly detected using SYBR Green. Amplification plots were highly reproducible between triplicate samples of the same treatment, and fluorescence data from negative controls
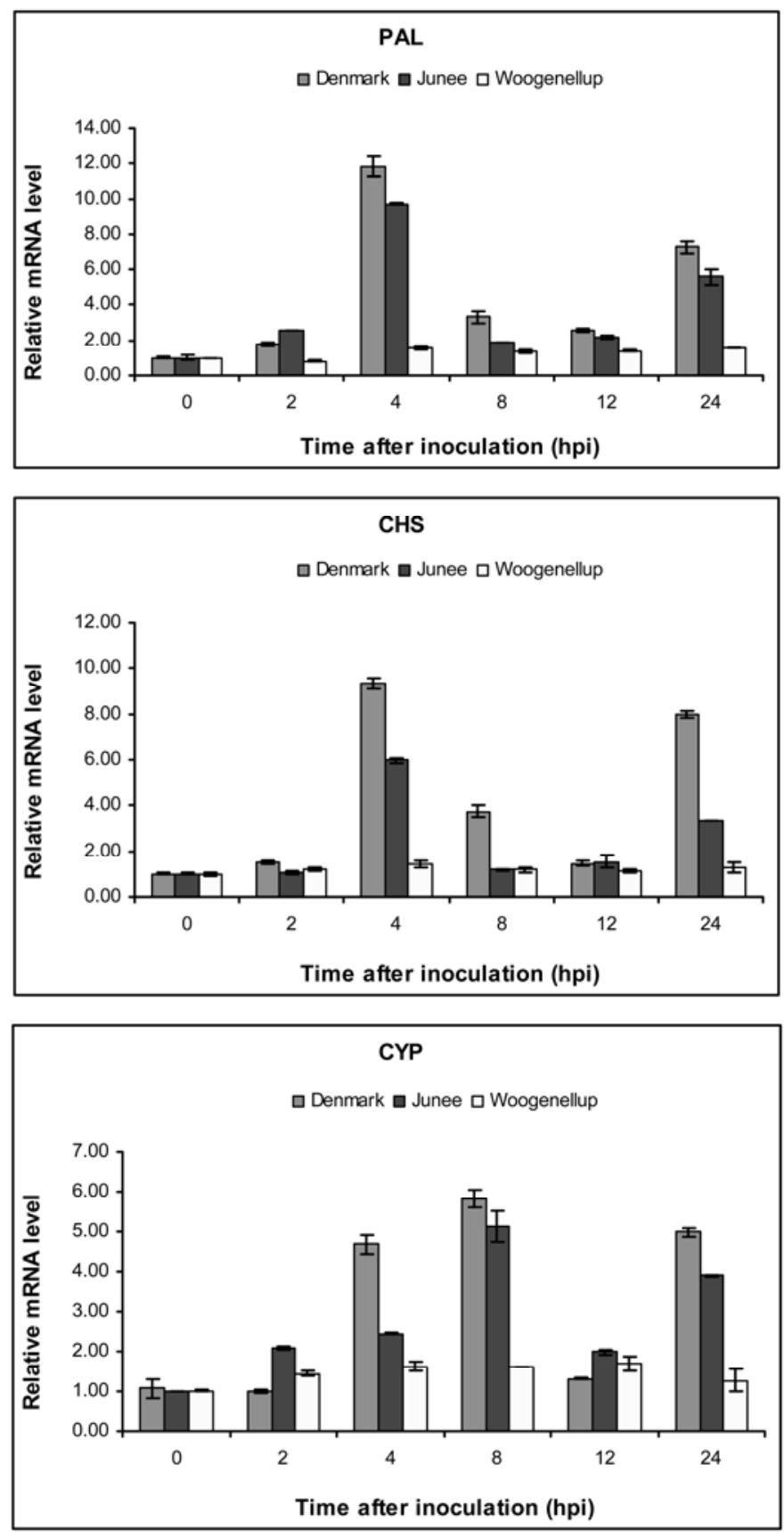

Fig. 3. Analysis of transcript levels by quantitative reverse transcriptionpolymerase chain reaction in two resistant cultivars of Trifolium subterraneum viz, Denmark and Junee, and one susceptible cultivar Woogenellup, following inoculation with Phytophthora clandestina Race 177. Values are expressed as mean \pm standard error for the relative mRNA expression level $(P<0.05)$. containing no templates always remained well below the threshold level.

Normalization. The amount of the 18S RNA did not show significant change between treatments $(P>0.05)$. However, transcript accumulation of the actin gene was found to vary considerably and was therefore not considered reliable as an internal control. Thus, the relative expression ratio of defenserelated genes in the treated plants versus the control was estimated by normalizing against $18 \mathrm{~S}$.

DNA sequences. RT-PCR products for defense-related genes (PAL, CHS, and CYP) were sequenced. The PAL gene product from mRNA showed $95 \%$ identity with a known PAL1 gene sequence (GenBank accession no. M91192) from T. subterraneum (18); the PAL amplicon from genomic DNA showed 95\% identity with the exon of the same known gene. The CHS amplicon sequence had $98 \%$ identity with a known $T$. subterraneum chalcone synthase (CHS3) gene (GenBank accession no. L24515.1) (19). There is no recorded $T$. subterraneum gene encoding cinnamic acid 4-hydroxylase; the closest match (92\% identity) for the sequence gained here was that of a cinnamic acid 4-hydroxylase gene from Trifolium pratense (GenBank accession no. EU574000). Sequences gained from this study were lodged with GenBank and accession numbers are recorded in Table 1.

Expression of defense-related genes during the infection process. There were significant differences $(P<0.05)$ in expression of defense-related gene transcripts among the treatments and the sampling times. mRNA levels for PAL, CHS, and CYP of resistant cvs. Denmark and Junee increased with time after inoculation with $P$. clandestina Race 177 (Fig. 3). The inoculation of cv. Woogenellup seedlings with $P$. clandestina Race 000, to which it is resistant, also induced stimulation of PAL, CHS, and CYP gene expressions (Fig. 4).

Defense-related gene activity in infected plants of three cultivars by Race 177. The inoculation of the roots of subclover seedlings with $P$. clandestina Race 177 induced stimulation of mRNA for PAL, CHS, and CYP activity in both resistant cultivars (Denmark and Junee) studied, with a maximum activity observed at 4 hpi for PAL and CHS, and 8 hpi for CYP (Fig. 3). However, the response of the cultivar susceptible to Race 177 (Woogenellup) showed no significant change. The postinfection activity of the genes for PAL in the resistant cultivars increased, reaching, at $4 \mathrm{hpi}$, a maximum activity 11 times higher than that of the control in cv. Denmark and 9 times that of the control in cv. Junee, the activity level then decreased almost to that of the control level, but at 24 hpi the levels of activity increased again to 5 times that in cv. Denmark and 4 times that in cv. Junee to that of the control. The postinfection activity of gene for CHS in the resistant cultivars showed the same trend as PAL, but reaching, at $4 \mathrm{hpi,} \mathrm{a}$ maximum activity 9 times higher than that of the control in cv. Denmark and 6 times that in cv. Junee. At $24 \mathrm{hpi}$, the level of activity increased again to a level 8 times higher than that of the control in cv. Denmark and 3 times that in cv. Junee. The postinfection activity of gene for CYP in the resistant cultivars was slightly different to that of the other two genes. The activity of this gene started increasing at 4 hpi for Denmark, reaching at 8 hpi, a maximum activity for both cvs. Denmark and Junee, which was 5 times higher than that of the control in cv. Denmark and 4 times to that in cv. Junee, the activity then decreasing almost to the level of the control at 12 hpi. However, at $24 \mathrm{hpi}$, its activity increased again to be 5 times higher than that of the control in $\mathrm{cv}$. Denmark and 3 times higher than that of the control in cv. Junee. In the susceptible cv. Woogenellup, all three genes activities remained weak $(<1.5$ times of the control) throughout the assessment period.

Defense-related gene activity in infected plants of cultivar Woogenellup by Race 000. The inoculation of cv. Woogenellup seedlings with $P$. clandestina Race 000, to which it is resistant, induced a stimulation of genes for PAL, CHS and CYP activity in 
the plant, with a maximum simulation observed at 4 hpi for PAL and CYP, and 24 hpi for CHS (Fig. 4). Postinfection activity of gene for PAL increased, reaching, at $4 \mathrm{hpi}$, a maximum level four times higher than that of the control. Activity level then decreased to almost the level of the control and remained weak. The postinfection activities of genes for CHS and CYP increased, reaching, at 4 hpi, 5 times greater than that of the control for both genes, their levels of activity then decreasing to almost those of the control, but at 12 hpi these activities increased again and reached a maximum activity 5 times and 4 times, respectively, higher than that of the control at 24 hpi.

\section{DISCUSSION}

This study demonstrated for the first time using real-time QRTPCR, the relationship of the activation of the genes encoding for PAL, CHS, and CYP to host resistance in subterranean clover to $P$. clandestina. The activation of these genes increased rapidly in incompatible cultivar/race interactions following inoculation. In contrast, the compatible cultivar/race interaction showed no significant change in levels of activation indicating that, as in other pathosystems, these genes play an important role in host resistance to the pathogen $(5,25,32)$.

The choice of the defense-related genes studied was dictated by the fact that all three genes have been reported to be involved in resistance of plants to infection by a variety of plant pathogens. The rate of accumulation of mRNA for PAL was reported to be higher in the incompatible interactions than in the compatible interactions between soybean and $P$. sojae (24), and in potato infected with $P$. infestans (32). The accumulation of mRNA for CHS was higher in the incompatible interactions in soybean hypocotyls and $P$. megasperma f. sp. glycinea (5). The expression level of $C Y P$ was higher in the incompatible interaction than in the compatible interaction between pepper and Colletotrichum gloeosporioides (25). PAL is the core enzyme in phenylpropanoid metabolism converting phenylalanine to cinnamic acid. Cinnamic acid 4-hydroxylase then converts cinnamic acid to p-coumaric acid. These two enzymatic steps are the first in a sequence leading from phenylalanine to complex phenylpropanoid compounds such as lignin and flavonoid phytoalexins in addition to the pathway leading to the signaling molecule, salicylic acid. PAL has also been implicated in the biosynthetic pathway for salicylic acid, and other defense related compounds and is a key signaling component required for the activation of pathogenesis-related genes, catalases, receptor-like protein kinases, and bZIP transcription factors (20).

Results from the present study showed that increased PAL activity was evident at $4 \mathrm{hpi}$, with increase of CYP at 4 to $8 \mathrm{hpi}$. This indicated that in this pathosystem, induction of the phenylpropanoid pathways occurs, leading to the synthesis of tryptophan, phenylalanine, and lignin, and is similar to that reported by Mauch-Mani et al. (22). The trend of increased PAL mRNA expression in incompatible interactions is consistent with other reports of interactions between plants and plant pathogens, such as potato infection by $P$. infestans $(31,32)$ and alfalfa with Colletotrichum trifolii (29). Previous work in PAL enzyme activity in the interaction in Eucalyptus with P. cinnamomi (7) and T. subterraneum infected by Kabatiella caulivora (3) also lead to the same conclusion.

Microscopy studies showed that zoospores of Race 177 of $P$. clandestina showed no differential attraction to roots of cv. Junee (resistant) or cv. Woogenellup (susceptible). Zoospores were mainly attracted toward the tip of the taproots, irrespective of the cultivar. Cysts germinated and penetrated the root within a few hours of inoculation on both cultivars. There were no significant effects of the host genotype during pre- or early-penetration phases. However, by $5 \mathrm{dpi}$, antheridia and oogonia were present both in the cortex and stele of the susceptible cultivar while the hyphae were restricted to four to six layers of cortical cells with no antheridia and oogonia formation in the resistant cultivar. By $8 \mathrm{dpi}$, oospores were present in the cortex and stele and sporangia were evident on the surface of the roots of the susceptible host, whilst there were no oospores or sporangia on the resistant cultivar. This indicates that the main host resistance responses to the pathogen in the cultivars tested occurred post-penetration. We believe this is the first study of the processes involved in resistant and susceptible cultivars of $T$. subterraneum to $P$. clandestina in relation to the spore attachment, germination, and penetration associated with infection and symptom development.
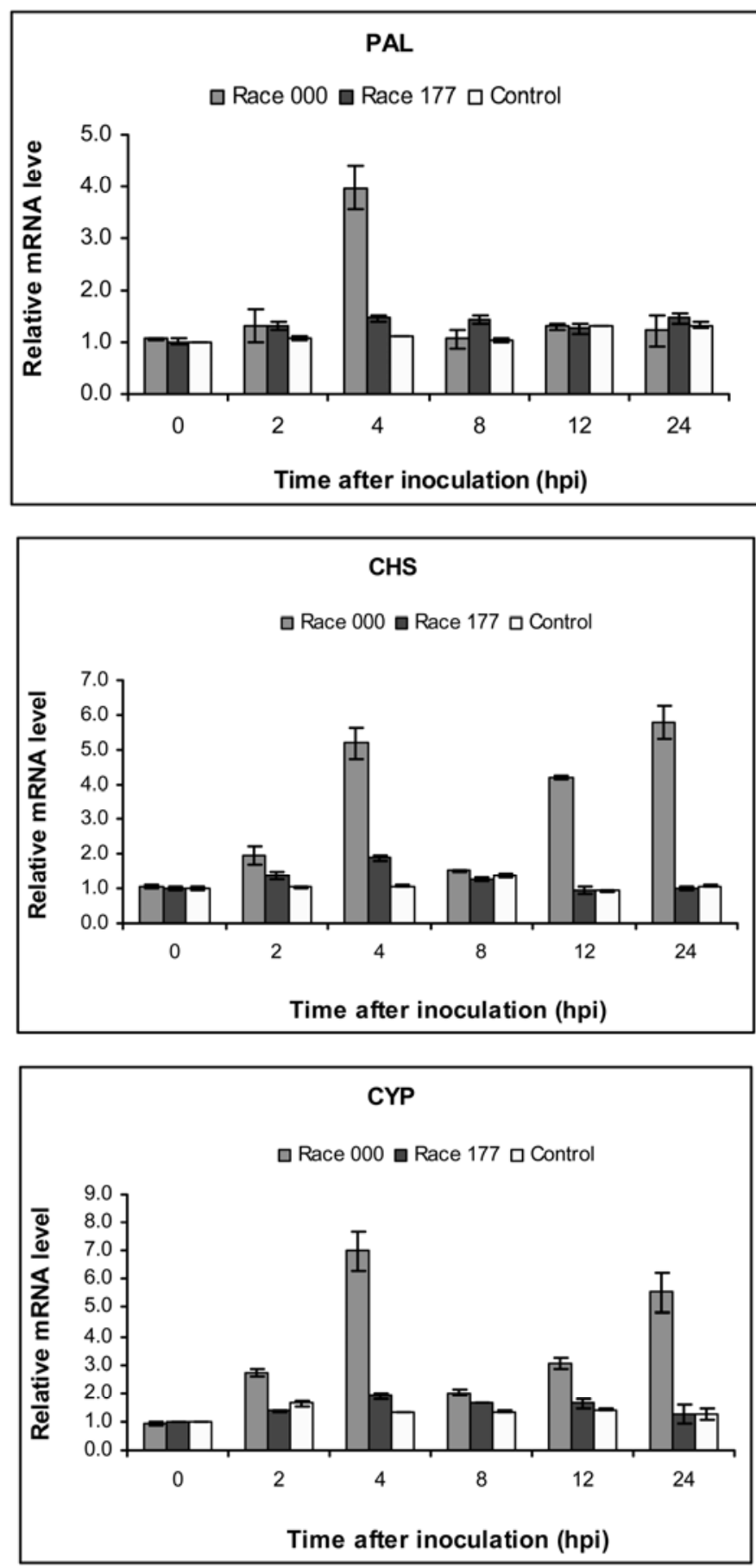

Fig. 4. Analysis of transcript levels by quantitative reverse transcription-polymerase chain reaction in Trifolium subterraneum cv. Woogenellup following inoculation with virulent Phytophthora clandestina Race 177 and avirulent Race 000. Values are expressed as mean \pm standard error for the relative mRNA expression level $(P<0.05)$. 
Variation in gene expression was determined during a time course experiment of the interactions between susceptible (Woogenellup) and resistant (Junee) cultivars. Early activation of resistance-related genes at $4 \mathrm{hpi}$ is not surprising considering that cysts of $P$. clandestina germinated 1 to 2 hpi of $T$. subterraneum and penetrated at 2 to $4 \mathrm{hpi}$. It is clear that time of activation of these defense genes is related to the infection behavior of the pathogens concerned. In a similar study involving compatible and incompatible interactions between potato cv. Datura and various $P$. infestans races, little difference was found in the rate of hyphal growth of the races until 12 to 14 hpi (10). By then, hyphae of all races had penetrated to the boundary between palisade parenchyma and upper epidermis, and a clear differential response in surrounding potato cells was observed; in the compatible interaction few cells showed a visible response, whereas in incompatible interactions parenchyma cells responded with rapid browning and necrosis. By $24 \mathrm{hpi}$, color intensity and size of the necrotic lesions had reached a maximum in the incompatible interaction. In contrast, at $24 \mathrm{hpi}$ in the compatible interaction, the hyphae had penetrated the upper epidermis and sporulation had commenced (10). In the present study, CYP transcript accumulation appears to be induced by 4 hpi and peaked by 8 hpi.

The spectrum of expression levels in our study for all three genes increased rapidly in incompatible reactions while they showed no significant change in compatible reactions during the period of observations ( 0 to $24 \mathrm{hpi}$ ), regardless of the cultivar or the pathogen race. However, there were clear differences in the activation of the three genes studied between the compatible and incompatible combinations of the cultivars of the host and races of the pathogen. Our results are similar to those of Bonhoff et al. (4) who also reported a threefold increased activity of the gene for CHS in soybean hypocotyls following an incompatible interaction with P. megasperma f. sp. glycinea. Esnault et al. (15) also found a similar response with that same pathosystem. Similarly, Yashioka et al. (32) showed that levels of PAL mRNA to be higher in potato resistant to $P$. infestans, while Chai and Doke (8) reported that the onset of resistance in potato leaves was evident in the generation of superoxide anions even before penetration of epidermis by $P$. infestans. Cuypers et al. (11) using in situ hybridization found PAL mRNA accumulation in young potato leaves within $3 \mathrm{~h}$ of inoculation with an incompatible race of $P$. infestans.

Interestingly, there were significant differences $(P<0.05)$ in expression of defense-related gene transcripts among the treatments and the sampling times determined by real-time QRT-PCR during the infection processes. By 4 hpi, Denmark and Junee induced a stimulation of mRNA for PAL, CHS, and CYP activities by Race 177. The activity level of CYP however increased to a maximum level at $8 \mathrm{hpi}$. The activity levels for all three decreased to almost to that of the control at $12 \mathrm{hpi}$, then rose again to peak at $24 \mathrm{hpi}$. Working with T. subterraneum, Bayliss et al. (3) found an 18-fold increase in the levels of PAL in the incompatible interaction with $K$. caulivora, the difference evident at $8 \mathrm{~h}$ and peaking at $48 \mathrm{~h}$. Cui et al. (9) observed CHS mRNA accumulation in incompatible interactions of sorghum with Peronosclerospora sorghi which was higher than in compatible interactions and found that high levels also persisted longer in the incompatible combination. Oh et al. (25) in their microscopic and in situ hybridization observations found that even before the cells of pepper fruits were in contact with the hyphae of the pathogen C. gloeosporioides, the induction of PepCYP was detected throughout the epidermal cell layers. They also reported that the mRNA accumulation of PepCYP was higher in the incompatible combination. Saunders and O'Neil (29) showed that in alfalfa resistant to $C$. trifolii, PAL activity was higher, especially 25 to $49 \mathrm{hpi}$. They also found a second increase in this activity at $97 \mathrm{hpi}$ when the disease level was most severe.

This study clearly indicates the involvement of the three genes studied with the expression of resistance, the activity of which was initiated early in the host-pathogen interaction. Differential gene expression of the resistant and susceptible hosts may reflect the infection behavior of specific races of $P$. clandestina. Because a large number of genes have been identified that are known to have roles in plant defense against pathogens (6), it is likely that many genes other than the three studied here are also involved in the expression of resistance in the pathosystem studied. The high levels of activation of these three genes can now be followed by studies on associated natural plant components and xenobiotics which may contribute towards the defense of the host plant against the invading pathogen.

\section{ACKNOWLEDGMENTS}

This work was supported by joint funding by the Australian Research Council (ARC) and the Department of Agriculture and Food Western Australia. We thank S. Han for the preparation of the inoculum for this study.

\section{LITERATURE CITED}

1. Aldaoud, R., Guppy, W., and Flett, S. 1997. Phytophthora root rot resistance in subterranean clover. Final project report (DAV155), International Wool Secretariat, Australia.

2. Barbetti, M. J., You, M. P., Li, H., Ma, X., and Sivasithamparam, K. 2007. Management of root diseases of annual pasture legumes in Mediterranean ecosystems-A case study of subterranean clover root diseases in the south-west of Western Australia. Phytopathol. Mediterr. 46:239-258.

3. Bayliss, K., Sivasithamparam, K., Barbetti, M. J., and Lagudah, E. 2001. Variability of phenylalanine ammonia-lyase and peroxidase activities in leaves of subterranean clover is determined by their susceptibility to Kabatiella caulivora. Phytopathol. Mediterr. 40:217-223.

4. Bonhoff, A., and Grisebach, H. 1988. Elicitor-induced accumulation of glyceollin and callose in soybean roots and localized resistance against Phytophthora megasperma f. sp. glycinea. Plant Sci. 54:203-210.

5. Bonhoff, A., Loyal, R., Ebel, J., and Grisebach, H. 1986. Race:cultivarspecific induction of enzymes related to phytoalexin biosynthesis in soybean roots following infection with Phytophthora megasperma f. sp. glycinea. Arch. Biochem. Biophys. 246:149-154.

6. Bowles, D. J. 1990. Defense-related proteins in higher plants. Annu. Rev. Biochem. 59:873-907.

7. Cahill, D. M., Bennett, I. J., and McComb, J. A. 1993. Mechanisms of resistance to Phytophthora cinnamomi in clonal, micropropagated Eucalyptus marginata. Plant Pathol. 42:865-872.

8. Chai, H. B., and Doke, N. 1987. Systemic activation of oxygen generating reaction superoxide dismutase and peroxidase in potato plants in relation to induction of systemic resistance to Phytophthora infestans. Ann. Phytopathol. Soc. Jpn. 53:585-590.

9. Cui, Y., Magill, J., Frederiksen, R., and Magill, C. 1996. Chalcone synthase and phenylalanine ammonia-lyase mRNA levels following exposure of sorghum seedlings to three fungal pathogens. Physiol. Mol. Plant Pathol. 49:187-199.

10. Cuypers, B., and Hahlbrock, K. 1988. Immunohistochemical studies of compatible and incompatible interactions of potato leaves with Phytophthora infestans and of the nonhost response to Phytophthora megasperma. Can. J. Bot. 66:700-705.

11. Cuypers, B., Schmelzer, E., and Hahlbrock, K. 1988. In situ localization of rapidly accumulated phenylalanine ammonia-lyase mRNA around penetration sites of Phytophthora infestans in potato leaves. Mol. PlantMicrobe Interact. 1:157-160.

12. Die, J. V., Dita, M. A., Krajinski, F., Gonzalez-Verdejo, C. I., Rubiales, D., and Moreno, M. T. 2007. Identification by suppression subtractive hybridization and expression analysis of Medicago truncatula putative defense genes in response to Orobanche crenata parasitization. Physiol. Mol. Plant Pathol. 70:49-59.

13. Duval, F. D., Renard, M., Jaquinod, M., Biou, V., Montrichard, F., and Macherel, D. 2002. Differential expression and functional analysis of three calmodulin isoforms in germinating pea (Pisum sativum L.) seeds. Plant J. 32:481-493.

14. Erwin, D. C., and Ribeiro, O. 1996. Phytophthora Diseases Worldwide. American Phytopathological Society, St. Paul, MN.

15. Esnault, R., Chibbar, R. N., Lee, D. , Van Huystee, R. B., and Ward, E. W. B. 1987. Early differences in production of messenger RNAs for phenylalanine ammonia-lyase and chalcone synthase in resistant and susceptible cultivars of soybean inoculated with Phytophthora megasperma f. sp. glycinea. Physiol. Mol. Plant Pathol. 30:293-298.

16. Flett, S. P. 1994. Studies on Phytophthora clandestina, the cause of 
taproot rot in subterranean clover: 1. Evidence for physiological specialization in Phytophthora clandestina. Aust. J. Exp. Agric. 34:11251129.

17. Greenhalgh, F. C., and Taylor, P. A. 1985. Phytophthora clandestina, cause of severe tap root rot of subterranean clover in Victoria, Australia. Plant Dis. 69:1002-1004.

18. Howles, P. A., Arioli, T., and Weinman, J. J. 1994. Characterization of a phenylalanine ammonia-lyase multigene family in Trifolium subterraneum. Gene 138:87-92.

19. Howles, P. A., Arioli, T., and Weinman, J. J. 1995. Nucleotide sequence of additional members of the gene family encoding chalcone synthase in Trifolium subterraneum. Plant Physiol. 107:1035-1036.

20. Klessig, D. F., Durner, J., Noad, R., Navarre, D. A., Wendehenne, D., Kumar, D., Zhou, J. M., Shah, J., Zhang, S. Q., Kachroo, P., Trifa, Y., Pontier, D., Lam, E., and Silva, H. 2000. Nitric oxide and salicylic acid signaling in plant defense. PNAS 97:8849-8855.

21. Lee, J., Feng, J., Campbell, K. B., Scheffler, B. E., Garrett, W. M., Thibivilliers, S. Stacey, G., Naiman, D. Q., Tucker, M. L., PastorCorrales, M. A., and Cooper, B. 2009. Quantitative proteomic analysis of bean plants infected by a virulent and avirulent obligate rust fungus. Mol. Cell Proteomics 8:19-31.

22. Mauch-Mani, B., and Slusarenko, A. J. 1996. Production of salicylic acid precursors is a major function of phenylalanine ammonia-lyase in the resistance of Arabidopsis to Peronospora parasitica. Plant Cell 8:203212.

23. McMaugh, S. J., and Lyon, B. R. 2003. Real-time quantitative RT-PCR assay of gene expression in plant roots during fungal pathogenesis. Biotechniques 34:982-986.

24. Moy, P., Qutob, D., Chapman, B. P., Atkinson, I., and Gijzen, M. 2004. Patterns of gene expression upon infection of soybean plants by Phytophthora sojae. Mol. Plant-Microbe Interact. 17:1051-1062.
25. Oh, B. J., Ko, M. K., Kim, Y. S., Kim, K. S., Kostenyuk, I., and Kee, H K. 1999. A cytochrome P450 gene is differentially expressed in compatible and incompatible interactions between pepper (Capsicum annuum) and the anthracnose fungus, Colletotrichum gloeosporioides. Mol. Plant-Microbe Interact. 12:1044-1052.

26. Pfaffl, M. W. 2001. A new mathematical model for relative quantification in real-time RT-PCR. Nucleic Acids Res. 29:2002-2007.

27. Purwantara, A., Flet, S. P., and Keane, P. J. 1998. The expression of resistance of subterranean clover cultivars to races of Phytophthora clandestina. Euphytica 102:71-79.

28. Purwantara, A., Flett, S. P., and Keane, P. J. 1998. Colonization of roots of subterranean clover cultivars by virulent and avirulent race of Phytophthora clandestina. Plant Pathol. 47:67-72.

29. Saunders, J., and O'Neill, N. 2004. The characterization of defense responses to fungal infection in alfalfa. BioControl 49:715-728.

30. Suzuki, H., Reddy, M. S. S., Naoumkina, M., Aziz, N., May, G. D., Huhman, D. V., Sumner, L. W., Blount, J. W., Mendes, P., and Dixon, R. A. 2004. Methyl jasmonate and yeast elicitor induce differential transcriptional and metabolic re-programming in cell suspension cultures of the model legume Medicago truncatula. Planta 220:696-707.

31. Trognitz, F., Manosalva, P., Gysin, R., Nino-Liu, D., Simon, R., and del Rosario Herrera, M. 2002. Plant defense genes associated with quantitative resistance to potato late blight in Solanum phureja $\times$ dihaploid S. tuberosum hybrids. Mol. Plant-Microbe Interact. 15:587-597.

32. Yoshioka, H., Miyabe, M., Hayakawa, Y., and Doke, N. 1996. Expression of genes for phenylalanine ammonia-lyase and 3-hydroxy-3-methylglutaryl CoA reductase in aged potato tubers infected with Phytophthora infestans. Plant Cell Physiol. 37:81-90.

33. You, M. P., Barbetti, M. J., and Sivasithamparam, K. 2005. Characterization of Phytophthora clandestina races on Trifolium subterraneum in Western Australia. Eur. J. Plant Pathol. 113:267-274. 